\section{Antibiotic prescribing pattern on extemporaneous compounding suspension in primary health care centers}

\author{
Indri Hapsari, ${ }^{1,2}$ Marchaban, ${ }^{3}$ \\ Chairun Wiedyaningsih, ${ }^{3}$ \\ Susi Ari Kristina ${ }^{3}$ \\ ${ }^{1}$ Faculty of Pharmacy, Universitas \\ Gadjah Mada; ${ }^{2}$ Department of \\ Pharmaceutics and Technology of \\ Pharmacy, Faculty of Pharmacy, \\ Universitas Muhammadiyah \\ Purwokerto; ${ }^{3}$ Department of \\ Pharmaceutics, Faculty of Pharmacy, \\ Universitas Gadjah Mada, Indonesia
}

\begin{abstract}
Extemporaneous compounding is one of traditional drug prescribing methods. Although this compounding is still used until present days, but it remains problems since many unexpected cases happen such as medication error, quality of the compounding and also bacterial contamination that may appear in each compounding dosage. This study aims to determine prescribing pattern of antibiotic on dosage of extemporaneous compounding suspension in primary health care centers. The employed method is cross sectional survey conducted in 24 primary health care centers; it is obtained 87 extemporaneous compounding suspensions containing antibiotics. The result shows the antibiotics frequently used in the compounding in the primary health care centers are amoxicillin $(90.62 \%)$ in form of tablet dosage (10.42) and suspension dosage $(89.58 \%)$. The most used pattern of antibiotic prescribing in dosage of extemporaneous prescribing suspension is antibiotic suspension + anti-histamine tablets + corticosteroids tablet (18.39\%). It can be concluded that the most used prescribing pattern of antibiotic in dosage of extemporaneous prescribing suspension is antibiotic suspension + anti-histamine tablets + corticosteroids tablet.
\end{abstract}

\section{Introduction}

Antibiotic use has been successfully decreasing number of morbidity and mortality caused by infections. This condition encourages excessive use of antibiotics. ${ }^{1}$ Since the past time, pharmacists have already practiced drug compounding as one of their basic competences and skills. In general, chemical dosage changing form (from the industrial drug products as its original form) into other medical forms was implemented in drug compounding; it was based on request and instruction of compounding personnel considering the patients' condition. ${ }^{2}$ Oral and topical are dosage forms of extemperanous compounding. ${ }^{3,4}$ Crushed tablet, capsule content (divided into smaller dosage), and also powders dissolved or suspended into the carrier liquid into an oral liquid are forms of oral dosage, ${ }^{5}$ whereas common dermatology in form of semi-solid of unguenta or cream is a form of the topical one. ${ }^{6}$

Although this drug compounding is still used until present days, but it remains problems since many unexpected cases happen such as medication error, quality of the compounding and also bacterial contamination that may appear in each compounding dosage. ${ }^{7}$ In some countries, the main consideration why doctors still apply drug compounding for their patients is shortage of licensed drug supply (especially drugs for pediatric patients). The shortage of licenced drugs insisted the doctors to use unlicenced or off label drugs in extemperanous compounding for pediatric patients, and it is considered as a common medication. ${ }^{2}$ The use of antibiotic in medicine and prescription is quite common in Indonesia. Although it is not required in a disease diagnosis, but sometimes antibiotics are still given to the patients. One of some cases is ARI (Accute Respiratory Infection); the disease is not necessarily caused by bacteria, but most patients suffered from ARI often get antibiotics in their medical therapy. ${ }^{8}$ A research conducted on patients with non-pneumonia ARI at Primary Health Care Center of Cengkareng Sub-district, Jakarta shows that the high use of antibiotics in a sample of patients $(59 \%)$ with the most widely used antibiotics is amoxicillin antibiotics. ${ }^{8}$ The use of antibiotics is quite often in medical treatment therapy, one of the consideration is due to demand from patients to obtain antibiotic therapy and also willingness of both parties (doctors and patients) to recover faster from the disease but frequently the use of antibiotics is not appropriate, because it only refers to the symptom not its diagnosis. ${ }^{8,9}$

Average of drug number given to patients in primary or government health centers in a sheet of prescription compounding is quite high; commonly it includes more than one drug given individually or prescribed together. It can be shown in a study conducted by Widyaswari and Wiedyaningsih (2012) in primary health care centers in Special Region of Yogyakarta; it shows that dosage forms of
Correspondence: Indri Hapsari, Doctoral Student, Faculty of Pharmacy, Universitas Gadjah Mada, Sekip Utara Yogyakarta Central Java 55281 Indonesia.

Tel.: +62.274.543120 - Fax: +62.274.543120

E-mail: indrihapsari_ump10@yahoo.co.id

Key words: Prescribing pattern, antibiotic, suspension, extemporaneous compounding, primary health care centers.

Acknowledgements: We would like to express our gratitude to Indonesian Lecturer Scholarship of Domestic Affairs (BUDI-DN), a collaboration between the Ministry of Research, Technology and Higher Education and Indonesia Endowment Fund for Education (LPDP). We would also like to thank to the Head of Regional Health Office and Heads of Public Health Centers in Banyumas Regency, Central Java, Indonesia.

Contributions: The authors contributed equally.

Conflicts of interest: The authors declare that there are no competing or potential conflicts of interest of the paper.

Funding: This project was supported by Indonesia Endowment Fund for Education (LPDP)

Clinical trials: the study is not involved any clinical trials.

Conference presentation: part of this paper was presented at the $3^{\text {rd }}$ International Symposium of Public Health, 2018 October 31 - November 1, Universitas Airlangga, Surabaya, Indonesia.

Dedication: This study is dedicated to Faculty of Pharmacy, Universitas Gadjah Mada, Indonesia and Faculty of Pharmacy, Universitas Muhammadiyah Purwokerto, Indonesia

Received for publication: 28 July 2019.

Revision received: 9 September 2019.

Accepted for publication: 15 October 2019.

This work is licensed under a Creative Commons Attribution NonCommercial 4.0 License (CC BY-NC 4.0).

${ }^{C}$ Copyright: the Author(s), 2019

Licensee PAGEPress, Italy

Journal of Public Health in Africa 2019; 10(s1):1183 doi:10.4081/jphia.2019.1183

extemporaneous compounding mostly prescribed in one dosage form are in three drugs with average drug use 2.8 drug per extemporaneous compounding, ${ }^{10}$ while another research conducted in one of primary health care centers in the region 
shows 320 of 313 patients got a single antibiotic and 7 patients got an antibiotic combination. ${ }^{11}$ Most of the pediatric patients in private clinics in Surabaya also received extemporaneous compounding $(92.11 \%)$ which were prescribed together with other drugs namely paracetamol. ${ }^{12}$ Even though the bigger amount of medication given to patients, the more polypharmacy will occur and it will further increase occurrence of medication errors. ${ }^{13}$ This study aims to determine prescribing pattern of antibiotics on dosage of extemporaneous compounding suspension in primary health care centers.

\section{Materials and Methods}

\section{Study design}

It is an observational study and it employs cross sectional descriptive survey method.

\section{Study area}

The prescribings set as its population are in form of extemporaneous compounding suspension obtained from 24 primary health care centers in Banyumas Regency, Central Java, Indonesia. This study was conducted since April to June 2017.

\section{Data collection and criteria}

Data collection is applied retrospectively. The sampling is carried out by stratified random sampling based on the large number of extemporaneous compoundin in each primary health care center.

\section{Inclusion criteria}

Inclusion criteria in this study is all extemporaneous compounding suspension containing antibiotics in pharmacy installation of primary health care center consisting of more than one drug/ active substance on each extemporaneous compounding suspension; 87 of 99 extemporaneous compounding suspensions contain antibiotics.

\section{Exclusion criteria}

Exclusion criteria in this study is extem- poraneous compounding suspension that do not contain antibiotics or extemporaneous compounding suspension containing antibiotics but only with one drug/active substance without compounding before it is given to patients.

\section{Data analysis}

Data are noted on data collection sheets and analyzed descriptively.

\section{Ethical approval}

The ethical approval is obtained from the Ethics Commission of the Faculty of Medicine, Universitas Jendral Soedirman, Indonesia.

\section{Results}

The results show that the most patients receiving extemporaneous compounding are in the age range between 2 to 5 years $(54.02 \%)$; it can be viewed in Table 1 .

The antibiotics used in extemporaneous compounding implemented in primary health care centers in Banyumas regency, Central Java are amoxicillin (90.62\%), cefadroxil $(4.17 \%)$, erythromycin $(4.17 \%)$, and chloramphenicol (1.04\%); it can be viewed in Figure 1. Dosage of antibiotics used in extemporaneous compounding suspension which is in form of tablet (10.42\%) and suspension (dry syrup suspended in a sirplus syrup/solvent) $(89.58 \%)$. The number of antibiotics used in extemporaneous compounding suspension consists of two antibiotics (one antibiotic with two dosage forms); it is $5.75 \%$ (Table 2)

Besides antibiotic, the most used drug in extemporaneous compounding suspension is dexamethasone $(33.82 \%)$, chlorpheniramine maleat $(19.61 \%)$, and glyceril guaikolat (13.73\%) (Table 3).

From the research result, drug/active substance besides antibiotics which are mostly prescribed (Table 3) and their drug class has its correlation where the most prescribed drug would impact to prescribed

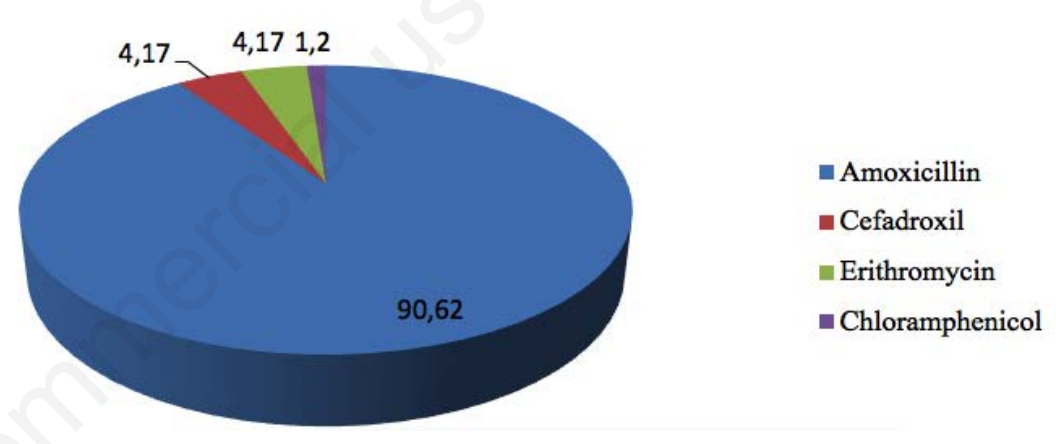

Figure 1. Antibiotics used in dosage form of compounding suspension.

Table 1. Patients receiving extemporaneous compounding suspension in primary health care centers $(\mathbf{n}=87)$.

\begin{tabular}{lcc} 
Age of patient (in year) & Number & Percentage (\%) \\
$0-1$ & 18 & 20.69 \\
$2-5$ & 47 & 54.02 \\
\hline $6-11$ & 21 & 24.14 \\
$12-17$ & 1 & 1.15 \\
\hline Total & 87 & 100 \\
\hline
\end{tabular}

Table 2. Number of antibiotics used in dosage form of compounding suspension in primary health care centers

\begin{tabular}{|c|c|c|c|c|}
\hline Number of antibiotics used & $\begin{array}{l}\text { Antibiotics with dosage form } \\
\text { (tablet/suspension) }\end{array}$ & Number & Percentage (\%) & Total percentage $(\%)$ \\
\hline One antibiotic & $\begin{array}{l}\text { Amoxicillin suspension } \\
\text { Cefadroxil suspension } \\
\text { Eritromycin suspension } \\
\text { Chloramphenicol suspension } \\
\text { Amoxicillin tablet }\end{array}$ & $\begin{array}{l}74 \\
4 \\
2 \\
1 \\
1\end{array}$ & $\begin{array}{l}85.05 \\
4.60 \\
2.30 \\
1.15 \\
1.15\end{array}$ & 94.25 \\
\hline Two antibiotics & $\begin{array}{l}\text { Amoxicillin suspension + Amoxicillin tablet } \\
\text { Eritromycin suspension + Erithromycin tablet }\end{array}$ & $\begin{array}{l}4 \\
1\end{array}$ & $\begin{array}{l}4.60 \\
1.15\end{array}$ & 5.75 \\
\hline Total & & 87 & 100 & 100 \\
\hline
\end{tabular}


drug class (Figure 2); dexamethasone is included in the corticosteroid class/group $(34.80 \%)$, chlorpheniramine maleat is included in the anti-histamine group (26.96 $\%$ ) and glyseril guaikolat is included in the ekspectorant group (15.20\%).

Number of active substances used in extemporaneous compounding suspension are 2 to 5 substances. Compounding suspension consisting of 3 and 4 active substances is the most prescribed suspension $(41.38 \%)$ it can be viewed in Figure 3.

Whereas the most prescribing pattern of antibiotics on extemporaneous compounding suspension is the dosage compounding consisting of 3 active substances; it is the combination between antibiotics and other non-antibiotic substances (Table 4).

The result shows that the most prescribed pattern of dosage of extemporaneous compounding suspension in primary health care centers is antibiotic suspension+anti-histamine tablet + corticosteroids tablet (it is $18.39 \%$ ).

\section{Discussion}

Based on the research results, patients who receive extemporaneous compounding containing antibiotics in primary health care centers in Banyumas regency are in the age range between 2 to 5 years $(54.02 \%)$. It is in line with the prescribing pattern at a children hospital in Kathmandu Valle, Nepal where those who get the most antibiotics are pediatric patients aged 1 to 5 years. ${ }^{14}$ It is also in line with a study entitled Prescribing of Extemporaneous Compounding Dosage on Pediatric Patients in Inpatient Wards of Yogyakarta Special Region; the most patients receive the compounding are aged above 6 years, ${ }^{15}$ and pediatric patients who get compounding with antibiotics at inpatient wards of RSI Sultan Agung, Semarang are in the age range between 1-4 years. ${ }^{9}$ It shows that the compounding is mostly given to pediatric patients which is caused by some factors; some of them is lack of drug supply/dosage especially for the pediatric patients, so the doctors prescribe the drugs to them. ${ }^{10}$

Based on the identification of extemporaneous compounding suspension containing antibiotics produced in primary health care centers in Banyumas regency, it is determined that in one dosage of compounding given to patients, there are 2 to 5 drugs with the biggest percentage consisting of 3 and 4 drugs in one dosage of extemporaneous compounding suspension $(41.38 \%)$. It is in line with the administration of antibiotics in hospitals, where based on the research conducted in pediatric wards; the use of combined antibiotics is
$20.5 \%$, with two combinations of 2 antibiotics $15.3 \%$ and more than two antibiotics $5.2 \% .{ }^{9}$ The number of prescribed drugs in a prescription sheet per-patient made in primary health care centers in some countries such as India and Saudi Arabia is almost the

Table 3. Drug/active substance (tablet) added into dosage of antibiotic compounding suspension in primary health care centers.

\begin{tabular}{lcc} 
Drug/active substance (tablet) & Number & Percentage (\%) \\
Chlorpheniramine maleat & 40 & 19.61 \\
Dexamethasone & 69 & 33.82 \\
\hline Glyseril guaikolat & 28 & 13.73 \\
Paracetamol & 17 & 8.34 \\
\hline Acid ascorbic & 16 & 7.84 \\
Vitamin B Complex & 2 & 0.98 \\
\hline Salbutamol & 2 & 0.98 \\
Ambroxol & 3 & 1.47 \\
\hline Prednisolone & 1 & 0.49 \\
Cetirizin & 15 & 7.35 \\
\hline Pyridoxine (Vitamin B6) & 2 & 0.98 \\
Metil Prednisolon & 1 & 0.49 \\
Ibuprofen & 1 & 0.49 \\
Antasida & 2 & 0.98 \\
\hline Asam mefenamat & 4 & 1.96 \\
Cyanocobalamine (Vitamin B12) & 1 & 0.49 \\
\hline Total & 204 & 100
\end{tabular}

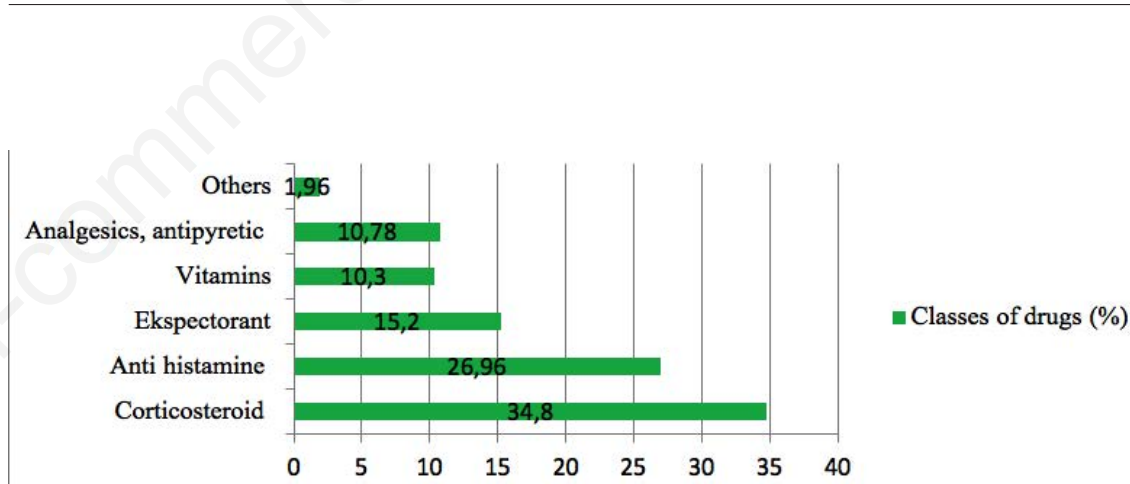

Figure 2. Drug class besides antibiotics added into dosage of compounding suspension.

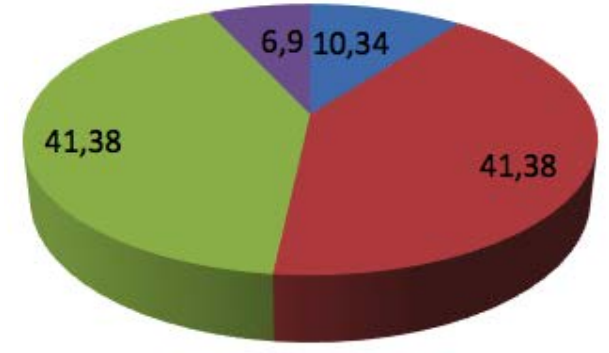

- 2 drug/active subtances - 3 drug/active subtances

4 drug/active subtances

- 5 drug/active subtances

Figure 3. Number of drug/active substance used in compounding suspension ( $n=87)$. 
(1.50) and Italia (1.46). ${ }^{16}$ The average number of drugs given in one extemporaneous compounding in Indonesia is quite high compared to health services in other countries, this could lead to polypharmacy and will further increase occurrence of medication errors. ${ }^{13}$

The used antibiotics in one dosage of extemporaneous compounding suspension is one antibiotic $(89.66 \%)$ and two antibiotics $(10.34 \%)$. Each antibiotic consists of amoxicillin suspension (85.05\%), cefadroxil suspension $(4.60 \%)$, erythromycin suspension $(2.30 \%)$, chloramphenicol suspension $(1.15 \%)$ and amoxicilline tablet $(1.15 \%)$. While combination of two antibiotics consists of 2 dosage forms namely amoxicillin antibiotic suspension + amoxicillin tablet and erythromycin suspension + eritromycin tablet. The result of this study is almost the same with another study result conducted by Muhlis (2010) at primary health care centers in Yogyakarta toward adult patients; the mostly used antibiotics was amoxicillin. ${ }^{11}$

Dosage form of antibiotics that mostly prescribed are in form of suspension and liquid dosage (89.58\%). It happens because most of the patients are pediatrics, so the liquid dosage would ease the children to consume the drugs. ${ }^{2}$ Although the most dosage of extemporaneous compounding in Indonesia is in form of puyer (crushed tablet), but liquid and suspension dosage are ranked two after the crushed tablet. ${ }^{4}$

The most prescribed drugs use in extemporaneous compounding at primary health care centers in Banyumas regency are chlorpheniramine maleate, dexamethasone, glyseril guaikolat, amoxicillin and paracetamol. This study result has similiarity with the prescribing pattern conducted by Widyasari and Wiedyaningsih at primary health care centers in Yogyakarta province (2012); the most prescribed drugs were chlorpheniramine maleate, glyceryl guaiacolate, vitamin $\mathrm{C}$ and paracetamol, but the use of antibiotics in Yogyakarta primary health care centers was relatively lower. ${ }^{10}$ If it is compared to prescribing of unlicensed drugs in several countries such as Netherlands and Switzerland, there are similarities in the most commonly prescribed drugs, paracetamol and amoxicillin, whereas in Brazil the drugs often prescribed is paracetamol. ${ }^{17-19}$

Antibiotic prescribing pattern on extemporaneous compounding suspension in primary health care centers of Banyumas regency, Central Java is various; the prescribing pattern consists of 2 to 5 five active substances; where the most prescribed is antibiotic prescribing in form of compounding suspension dosage consisting of 3 active substances with the prescribing pattern: antibiotic suspension+ Anti-histamine tablet + orticosteroid tablet, which is the combination between amoxicillin suspension, chlorpheniramine maleat tablet and dexamethasone tablet.

The use of high and inappropriate antibiotics can cause antibiotic resistance, ${ }^{20}$ the resistance has not only an impact on patient's clinical condition, but also an economic impact because the disease can get worse or cannot even heal due to the resistance; then it might make the patients spent more costs to recover from the disease. ${ }^{1} \mathrm{In}$ addition, the presence of a mixtured drugs other than antibiotics in the suspension dosage can also affect quality and stability of active substances prescribed concurently, which is worried to affect therapeutic effects of drugs given to the patients. Therefore, there needs to be an increase, supervision, evaluation and involvement of all parties, both from the government, medical personnel and also the community in the proper use of antibiotics so that it is expected to reduce the incidence of antibiotic resistance in the community.

Table 4. Prescribing pattern of antibiotics on dosage of compounding suspension

\begin{tabular}{|c|c|c|c|}
\hline $\begin{array}{l}\text { Number of drug/ } \\
\text { active substance }\end{array}$ & Prescribing & $\begin{array}{l}\text { Number } \\
\text { pattern }\end{array}$ & $\begin{array}{c}\text { Percentage } \\
(\%)\end{array}$ \\
\hline 2 active substances & $\begin{array}{l}\text { Antibiotics Susp. + Corticosteroid Tab } \\
\text { Antibiotics Susp. + Anti-histamine Tab } \\
\text { Antibiotics Susp. + Antibiotics Tab }\end{array}$ & $\begin{array}{l}4 \\
1 \\
4\end{array}$ & $\begin{array}{l}4.60 \\
1.15 \\
4.60\end{array}$ \\
\hline 3 active substances & $\begin{array}{l}\text { Antibiotics Susp. + Anti-histamine Tab + Corticosteroid Tab } \\
\text { Antibiotics Susp. + Anti-histamine Tab + Expectorant Tab } \\
\text { Antibiotics Susp. + Anti-histamine Tab + Vitamin Tab } \\
\text { Antibiotics Susp. + Anti-histamine Tab + Analgetik, Antipyretic Tab } \\
\text { Antibiotics Susp. + Corticosteroid Tab + Vitamin Tab } \\
\text { Antibiotics Susp. + Corticosteroid Tab + Analgetic, Antipyretic Tab } \\
\text { Antibiotics Susp. + Corticosteroid Tab + Anti Asthmatic Tab } \\
\text { Antibiotics Susp. + Corticosteroid Tab + Anti Gastrointestinal Tab } \\
\text { Antibiotics Susp.+ Corticosteroid Tab + Expectorant Tab } \\
\text { Antibiotics Susp. + Expectorant Tab + Anti Gastrointestinal Tab }\end{array}$ & $\begin{array}{l}16 \\
3 \\
2 \\
1 \\
4 \\
5 \\
1 \\
2 \\
1 \\
1\end{array}$ & $\begin{array}{l}18.39 \\
3.44 \\
2.30 \\
1.15 \\
4.60 \\
5.75 \\
1.15 \\
2.30 \\
1.15 \\
1.15\end{array}$ \\
\hline 4 active substances & $\begin{array}{l}\text { Antibiotics Susp + Anti-histamine Tab + Corticosteroid Tab+ Vitamin Tab } \\
\text { Antibiotics Susp. + Anti-histamine Tab + Corticosteroid Tab + Expectorant Tab } \\
\text { Antibiotics Susp. + Anti-histamine Tab + Corticosteroid Tab + Analgetic, Antipyretic Tab } \\
\text { Antibiotics Susp. + Anti-histamine Tab + Ekspectorant Tab+ Vitamin Tab } \\
\text { Antibiotics Susp. + Anti-histamine Tab + Ekspectorant Tab + Analgesic, Antipyretic Tab } \\
\text { Antibiotics Susp. + Corticosteroid Tab + Anti Asthmatic Tab + Anti histamine Tab } \\
\text { Antibiotics Susp. + Corticosteroid Tab + Ekspectorant Tab + Vitamin Tab } \\
\text { Antibiotics Susp. + Corticosteroid Tab + Analgetic, Antipyretic Tab + Ekspectorant Tab } \\
\text { Antibiotics Susp. + Corticosteroid Tab + Analgetic, Antipyretic Tab + Vitamin Tab } \\
\text { Antibiotics Susp. + Antibiotics Tab + Anti-histamine Tab + Corticosteroid Tab }\end{array}$ & $\begin{array}{l}4 \\
9 \\
4 \\
2 \\
2 \\
1 \\
2 \\
6 \\
1 \\
5\end{array}$ & $\begin{array}{l}4.60 \\
10.34 \\
4.60 \\
2.30 \\
2.30 \\
1.15 \\
2.30 \\
6.89 \\
1.15 \\
5.75\end{array}$ \\
\hline 5 active substances & $\begin{array}{l}\text { Antibiotics Susp. + Anti-histamine Tab + Corticosteroid Tab + Ekspectorant Tab + Vitamin Tab } \\
\text { Antibiotics Susp. + Anti-histamine Tab + Corticosteroid Tab + Ekspectorant Tab + Analgetic, Antipyretic Tab } \\
\text { Antibiotics Susp. + Anti-histamine Tab + Corticosteroid Tab + Analgetic, Antipyretic Tab + Vitamin Tab } \\
\text { Antibiotics Tab + Ekspectorant Syrup + Corticosteroid Tab + Analgetic, Antipyretic Tab + Vitamin Tab }\end{array}$ & $\begin{array}{l}3 \\
1 \\
1 \\
1\end{array}$ & $\begin{array}{l}3.44 \\
1.15 \\
1.15 \\
1.15\end{array}$ \\
\hline otal & & 87 & 100 \\
\hline
\end{tabular}




\section{Conclusions}

The most patients receiving extemporaneous compounding suspension containing antibiotics are patients in the range age of 25 years old $(54.02 \%)$, amoxicilline antibiotic is the most prescribed antibiotics in dosage of compounding suspension $(90.62 \%)$ with the most used prescribing pattern is antibiotic suspension + anti-histamine tablet + corticosteroids tablet $(18.39 \%)$.

\section{References}

1. Nouwen JL. Controlling antibiotic use and resistance. The University of Chicago Press; 2006.

2. Giam JA, McLachlan AJ. Extemporaneous product use in paediatric patients: a systematic review. Int J Pharm Pract. 2008;16(1):3-10.

3. Kristina SA, Wiedyaningsih C, Widyakusuma NN, et al. Extemporaneous Compounding Practice By Pharmacists: A Systematic Review. Int J Pharm Pharm Sci. 2017;1:9(2):42.

4. Hapsari I, Marchaban M, Wiedyaningsih $\mathrm{C}$, et al. The Extemporaneous Compounding at Primary Health Care Centers: Characteristic and Personnel. Glob J Health Sci. 2018;10(9):112.

5. Brion F, Nunn AJ, Rieutord A. Extemporaneous (magistral) preparation of oral medicines for children in
European hospitals. Acta Paediatr. 2003;92(4):486-490.

6 . Thiers BH. Compounding is still appropriate in clinical practice. Dermatol Clin. 1998;16(2):329-330.

7. Allen LV. Contemporary Pharmaceutical Compounding. Ann Pharmacother. 2003;37(10):1526.

8. Sauriasari R, Aulia AAH, Swastika A. The Evaluation of prescription conformity on non-penumonia upper respiratory tract infection cases in Integrated Management of Childhood Illness (IMCI) division at Cengkareng District Community Health Centre, Jakarta. Pharm Sci Res PSR. 2017;4(2):81-87.

9. Purwaningsih AEDA, Rahmawati F, Wahyono D. Evaluation of antibiotics pediatric patients ward. J Manaj Dan Pelayanan Farm. 2015;5(3):211-218.

10. Widyaswari R, Wiedyaningsih C. Evaluation Of Compounding Prescription Profile And Availability Of Medicine Pediatric Formulation In Primary Health Care Diy Province. Maj Farm. 8(3):227-234.

11. Muhlis M. Antibiotic Utilization of Adult Patients in One of The Public Health Center of Yogyakarta City Period January - April 2010. Pharmaciana. 2011;1(1).

12. Krisnanta KAB, Parfati N, Presley B, et al. Analysis of Profile and Contributing Factors to Non-Adherence towards Antibiotics Utilization Among Caregivers of Paediatric Patients. J Manaj and Farm J Manag Pharm Pract. 2018;8(1):39-50.
13. Koper D, Kamenski G, Flamm M, et al. Frequency of medication errors in primary care patients with polypharmacy. Fam Pract. 2013;30(3):313-9.

14. Palikhe N. Prescribing pattern of antibiotics in pediatric hospital of Kathmandu valley. Age Mean SD Years. 2004;4:39.

15. Hapsari I, Marchaban M, Wiedyaningsih $\mathrm{C}$, et al. Prescribing Pattern of Extemporaneous Compounding in Primary Health Care Centers. Global Journal of Health Science 2018;10(12):104-115.

16. O'Brien B. Patterns of European diagnoses and prescribing. Office of Health Economics; 1984.

17. Dos Santos L, Heineck I. Drug utilization study in pediatric prescriptions of a university hospital in southern brazil: off-label, unlicensed and high-alert medications. Farm Hosp. 2012;36 (4):180-6.

18. Di Paolo ER, Stoetter H, Cotting J, et al. Unlicensed and off-label drug use in a Swiss paediatric university hospital. Swiss Med Wkly. 2006;136(13/14):218.

19. 't Jong G, van der Linden P, Bakker E, et al. Unlicensed and off-label drug use in a paediatric ward of a general hospital in the Netherlands. Eur J Clin Pharmacol. 2002;58(4):293-7.

20. Lieberman JM. Appropriate antibiotic use and why it is important: the challenges of bacterial resistance. Pediatr Infect Dis J. 2003;22(12):1143-1151. 


\section{Relationship between spiritual quotient and self-adjustment of students at Jabal Nor Islamic Boarding School, Sidoarjo, Indonesia}

\author{
Khamida, Rizqy Mubarak, \\ Syiddatul Budury
}

Nursing and Midwifery Faculty, Universitas Nahdlatul Ulama Surabaya, Indonesia

\begin{abstract}
Adjusting to a life at Islamic boarding schools can be a very unique experience, many students are struggling and trying to cope with this new situation. The purpose of this research was to determine the correlation between spiritual quotient and the adjustment of student at Islamic Boarding School. The analysis method involved a cross sectional approach, with a population size was 60 students of class VII, who live in boarding school. Furthermore, a large sample size of 53 people was selected; using simple random technique, with the independent variable being spiritual quotient and the dependent was self-adjustment. Data analysis used a Chi-Square test, where hipotesis $\mathrm{H} 1$ is accepted if $\rho<\alpha=$ 0.05 . The results showed that all respondents, who had low spiritual quotient, possessed a negative self-adjustment compared with other respondents. Chi-Square statistical test results, with a significant level $\alpha=$ 0.05 obtained the value of $\rho(0.000)$, indicating a relationship between spiritual quotient and adjustment. In conclusion, a better spiritual quotient possessed by student, affects the process of adjustment.
\end{abstract}

\section{Introduction}

Every individual has their own way to solve problems faced in life, which are often caused by numerous conditions, within or outside. The process of adaptation to a new environment could not be ranked as being good or bad, however, the process could be addressed as a collaboration of mental responses and their acts, which triggers them to solve stressors, frustration and conflicts in their mind. Furthermore, this progression is needed by everyone who just entered new surroundings, one of which is the Islamic boarding school.

Based on the statement of the caretaker at Jabal Noer Islamic Boarding School Geluran Sub District, the atmosphere does- n't mean everything is okay because often time, the students meet obstacles on their way to adaptation, simply because they were forced to be admitted into the boarding institute. Furthermore, there are lots of things to be done and it is something really different from their habit, which becomes their main problem, as a new life forces them to be independent and far away from their parent and status. Students of Islamic boarding school, have to do a quick adaptation, reach some achievements and have a broadened knowledge about the spiritual part of the religion. The problems faced could come from the physical new environment and the social life, recent obligations and also different cultures. Furthermore, the institution students are forced to be able to act exactly like their religious task, bounded by their spiritual experience and any other mechanism, as a complement to reach the happiness of life.

From the department of Research and Development, Ministry of Religion Indonesia, it was reported that the 25,000 Islamic boarding schools in the 34 provinces in Indonesia, holds 3.65 million students. ${ }^{1}$ Furthermore, the report of Indonesian Religion Department (2017), stated that the amount of this institution of learning, surmounted to 28,691 , with 4,028,660 students, of which, 2,060,029 of them are males and 1,968,631 are females. In East Java alone, there are 6,017 Islamic boarding schools, with 455,807 females and 511,149 males, while data collected with the first survey on 27th January 2018 at Jabal Noer Islamic Boarding School, Geluran Sub District of Sidoarjo, illustrated the total number of students was 224, 109 and 115 of them were males and females respectively. On the 27th January, 2018, according to the interview with 10 students, 6 of which were new students, it was mentioned that they rarely join activities, often came out from the class before the time is over, had problems following the new rules, really wanted to return home because of lack of comfort and a fully booked schedule and also they were forbidden to bring with them a hand phone to school. Furthermore, 4 students said that they have no problem in Islamic boarding school and that they could join all activities, though a persuasive effort was first required from the caretaker.

The adaptation itself is affected by a few factors, including, physical condition, because a good body system supports good adaptation too, therefore, if there is a disability or chronic disease, it becomes the background of the obstacle itself. Furthermore, the pattern of adjustment in every person is different, in a line with the inherent mental growth, including retreat-
Correspondence: Khamida, Nursing and Midwifery Faculty, Universitas Nahdlatul Ulama Surabaya, SMEA Street 57, Surabaya, Jawa Timur 60243, Indonesia.

Tel.: +62.31.8291920 - Fax: +62.31.8298582

E-mail:khamida@unusa.ac.id

Key words: Spiritual Quotient, self adjustment, student.

Acknowledgements: The authors would like to appreciate respondents who were very cooperative and also Jabal Nor Islamic Boarding School principal and commission on board, for providing us with all facility that were required. Furthermore, we also express gratitude to the Universitas Nahdlatul Ulama Surabaya, for supporting us.

Contributions: the authors contributed equally

Conflict of interests: The authors declare no potential conflict of interest.

Funding: This project was supported by Universitas Nahdlatul Ulama Surabaya

Conference presentation: part of this paper was presented at the $3^{\text {rd }}$ International Symposium of Public Health, 2018 October 31 - November 1, Universitas Airlangga, Surabaya, Indonesia.

Dedication: This study is dedicated to all of Student Islamic Boarding School in Indonesia, and also to nursing science all over the world.

Received for publication: 28 July 2019

Revision received: 9 September 2019.

Accepted for publication: 15 October 2019.

This work is licensed under a Creative Commons Attribution NonCommercial 4.0 License (CC BY-NC 4.0).

C Copyright: the Author(s), 2019

Licensee PAGEPress, Italy

Journal of Public Health in Africa 2019; 10(s1):1184 doi:10.4081/jphia.2019.1184

ing from childish ways, to respond to the environment. However, this is not only a learning process because it's simply a function of the individual becoming more mature than before. ${ }^{1}$

Grade of religion and religious culture are another factor that contributed to reduce stressful, conflict, frustration and any other psychologist pressure because being religious, by virtue of an enhanced spirituality, gives a value and belief, where the individual has worth, aim and stability to face the pressure and change in their life. Furthermore, the quotient in their spiritual side thus builds their character and strength, during the process, hence, with an upgrade 